\title{
STRATEGI PENGAWASAN LURAH TERHADAP EFEKTIVITAS PEMUNGUTAN PAJAK BUMI DAN BANGUNAN DI KELURAHAN LAWAWOI KABUPATEN SIDENRENG RAPPANG
}

\author{
1)Evi, 2)Herman Dema, ${ }^{3)}$ Muhammad Rusdi \\ Fakultas IImu Sosial dan IImu Politik Universitas Muhammadiyah Sidenreng Rappang \\ evilansisumarni@gmail.com
}

\begin{abstract}
Abstrak
Strategi pengawasan lurah di kantor Kelurahan Lawawoi dan bagaiman efektivitas pemungutan pajak bumi dan bangunan (PBB) di kantor Kelurahan Lawawoi dan untuk mengetahui strategi pengawasan lurah terhadap efektivitas pemungutan pajakbumi dan bangunan(PBB) dikantor Kelurahan LawawoiKecamatan wattang puluh KabupatenSidenreng Rappang. Populasi dalam penelitianini adalah 859 Kepala Keluarga yang dimana pengambilan sampel yang digunakan yaitu Probability Sampling, dengan teknik sampling acak/random sampling dengan menggunakan Rumus Yount 10\% dengan jumlah sampel 86 Kepala Keluarga, Penelitian ini menggunakan Metode Deskritif Kuantitatif.Teknik Pengumpulan data yang digunakan melaluiObservasi, Kuisioner, danDokumentasi.TeknikAnalisis data yangdigunakan adalah analisis. Hasil penelitian ini menujukkan bahwa rata-rata persentase Strategi Pengawasan di kantor kelurahan lawawoi kabupaten Sidenreng Rappang sebesar $75,5 \%$ dengan kategori baik, efektivitaspemungutan pajakbumi dan bangunan(PBB) dikantor kelurahan LawawoiKecamatan wattang puluh Kabupaten SidenrengRappang sebesar $48,00 \%$ dengan kategori cukup baik dan Strategi pengawasan lurah terhadap efektivitaspemungutan pajakbumi dan bangunan dikantor kelurahan LawawoiKecamatan wattang pulu Kabupaten SidenrengRappang sebesar 16,0\% dengan kategori berpengaruh.
\end{abstract}

Kata Kunci : Efektivitas Pemungutan Pajak Bumi dan Bangunan (PBB).

\begin{abstract}
Thepurpose ofthis researchis to determine theLurah SupervisionStrategy on the Effectiveness of Land and Building Tax (PBB) collection in Lawawoi Village, Sidenreng Rappang Regency. The population taken in this study were all household heads in the Lawawoi Village, Sidenreng Rappang Regency, as many as 859 households and a sample of 86 households. The sampling technique used is probability sampling. Thistype ofresearch isdescriptive quantitative. Datacollection techniques are observation, interview, questionnaire (questionnaire) and literature study. Thedata analysis technique usedin this studywas descriptive statistics. Based on research that is taken from the results of the questionnaire, it is obtained that the recapitulation of variable $X$ (Supervision Strategy) reaches a value of $75.5 \%$ including the "good" category, and the recapitulation of variable $Y$ (effectiveness) reaches a value of $48 \%$ including the "poor" category.
\end{abstract}

Keywords: Supervision Strategy and Effectiveness

PRAJA | Volume 7 | Nomor 2 | Edisi Juni 2019 


\section{A. PENDAHULUAN}

Adisasmitaa (2010) otonomi daerah adalah untk mengurus sendiri rumah tangganya. Kewnangan yang dimaksud dapat berupa pengelolaan keuangan yang sumbernya berasal dari Pendapatan Asli Daerah (PAD), dana perimbangan, pinjaman daerah, dan penerimaan lain-lain yang sah. (Bratakusumah dan Solihin, 2001). Pajak daerah merupakan pajak yang dilakukan olehorang pribadi ataubadan kepada daerah tanpa imbalan yang seiimbang yg dapat diipaksakan berdsarkan peraturan perundang-undangan yg berlaku untuk membiayai penyelenggaraan pemerintahan daerah dan pembangunan.

Sumber sumber penerimaan pajak menurut Undang-Undang Nomor 28Tahun 2009 Pasal2 Ayat3 Tentang Pajak Hotel, Pajak Restoran, Pajak Hiburan, Pajak Reklame, Pajak Penerangan Jalan, Pajak Parkir, Pajak Mineral Bukan Logam dan Batuan, Pajak Air Tanah, PajakSarang Burung Walet, Pajak PBB Pedesaan dan Perkotaan,dan Bea Perolehan Hakatas Tanah dan Bangunan. Berdasarkan data yang diperoleh di Kantor KeLurahan Lawawoi Kecamatan Wattang Puluh dapat digambarkan jumlah wajib pajak yang aktif diKantor Lawawoi Kecamatan Wattang Pulu pada tahun 2018 dan 2019 berjumlah 3.386 wajib pajak, dengan potensi kurang lebih Rp.118.215.506, diberikanpula jumlah tunggakan pajak yang dimiliki olehwajib pajakitu sendiri. Data yang diperoleh, diketahui bahwa jumlah tunggakanyang dimilikiadalah sebesarRp. 19.625.000.dari tahun 2018 sampai dengan tahun 2019.Untuk sementara tunggakan tersebut sementara diperiiksaoleh Badan Pemeriksa Keuangan Daerah (BPKD) untuk mendapatkan arahan yang jelas mana tunggakan yang kadaluarsaan mana yang kemungkinan bisa ditagih untuk menghindari agar tidak terjadi permasalahan dikemudian hari.

Besarnya tunggakan yang terjadi tentu akan berpengaruh terhadap efektivitas penerimaan Pajak Bumi dan Bangunan (PBB) diLawawoi Kecamatan Wattang Pulu, mengingat pajak merupakan penerimaan terbesaran yang diperoleh pemerintahan daerah.Tentunya pemerintah daerah mempunyai strategi tertentunya yangdapat digunakan untuk mengoptimalkan penerimaan Pajak Bumi dan Bangunaan (PBB),terlebih lagi pengelolaan Pajak Bumi e-ISSN 2716-165X

dan Bangunaan (PBB) Pedesaan dan Perkotaan telah menjadi tanggung jawab pemerintah daerahnya. Berdasarkan observasinya yang dilakukan oleh calon penelitian dengan Pak Lurah, Staff dan beberapa Masyarakat di Kantor KeLurahan Lawawoi Kecamatan Wattang Pulu Kabupaten Sidenreng Rappang masalah yang ditemukan calon peneliti yaitu :

1. Keberhasilan Wajib Pajak PBB

Pembayaran Wajib Pajak dan Bagunan yangselama iniditemukan bahwa pembayaran pajak bumi dan bangunan 2 tahun terakhir tidak mencapaian target, dan seriingkalinya untuk mentupi kekurangaan tersebut kepala keLurahan atau Lurah Lawawoi menggunakan uang pribadi/kas Lurah untuk membayar pajak bumi dan bangunan sambil menunggu pembayarannya dari masyarakat.

2. Ditemukan juga bahwa Kolektor/penagih pajak tidak melaksanakaan tugasnya dengan maksimal, hal ini terlihat ketika masih banyak jumlah PBB yang belum di setujuii oleh Kantor Lurah Lawawoi atau tungakan yang belum lunas

3. Kurangnya kesadaraan masyarakatnya dalam membayaran PBB, hal ini terlihat ketika waktu pembayarannya PBB akan tiba akan tetapi justru masyarakat tidak terlalu memperhatkannya dengan pembayran PBB.

4. kurang tegasnya pemerintahan dalam memberiikan sanksi terhadp penunggak wajib PBB serta Rendhnya pengawasan pemerinah dalam pembayarannya PBB sehingga banyak masyarakat yang tidak terlalu memperhatikan PBB.

Berdasarkan uraian diatas, maka penulis tertarik untuk mengadakan penelitian dengan judul strategi pengawasan lurah terhadap efektivitas pemungutan pajak bumi dan bangunan di Kelurahan Lawawoi Kabupaten Sidenreng Rappang dengan tujuan untuk Mengetahui srategis pengawasan Lurah terhadap efektifitas pemungutan Pajak Bumi dan Bangunan (PBB) di KeLurahan Lawawoi Kecamatan Watang Pulu Kabupaten Sidenreng Rappang dan untuk mengetahui Efektivitas Pemungutan Pajak Bumi dan Bangunan (PBB)di KeLurahan Lawawoi Kecamatan Watang Pulu Kabupaten Sidenreng Rappang.

Pengawasan sebagai proses dalam menetapkan ukuran kinerja dan pengambilan tindakan yang dapat mendukung pencapaian 
hasil yang diharapkan sesuai dengan kinerjayang telah ditetapkan tersebut, Suledan saifullah (2005:317). Sementara berkaitan dengan tujuan pengawasan, menurut sule dan saifullah (2005 : 318-319) adaempat tujuan pengawasan tersebut adalah adaptasi lingkungan, meminimumkan kegagalan, meminumumkan biaya, dan mengantisipasi kompleksitas dari organisasi. Undang-undang No. 23 Tahun 2014 tentang pemerintahan daerah bahwa kedudukan kelurahan terdapat pada pasal 209 ayat (2) kelurahan bukan lagi sebagai perangkatdaerah. Melainkan menjalankan fungsi pendelegasian kewenangan yang diberikan camat sebagai perangkat pemerintahan terendah. Sujamto pengawasan memiliki beberapa bentuk, yaitu

1. Pengawasan umum merupakan cara untuk melakukan pengawasan atas jalannya pemerintahan daerah.

2. Pengawasan melekat iyalah pengawasan yang dilakukan oleh setiap pejabat dalam menjalankan tugasnya.

3. Pengawasan langsung adalah cara mendatangi dan melakukan pemeriksaan ditempat (on the spot) terhadap objek yang diawasi.

4. PengawasanTidak Langsung merupakan pengawasan dari jarak jauh lokasi atau tempat kejadian peristiwa (TKP).

Efektivitas menurut Abdul Jabbar, Halim (2004,:129) menyatakan efektivitas menggambarkan kemampuan pemerintah daerah dalam merealisasikan PAD yang direncanakan dibandingkan dengan target yang ditetapkan berdasarkan potensi riil daerah. Sedangkan pengertian efektivitas yang dikemukakan oleh Mardiasmo (2004, h.2) menyatakan bahwa kontribusi output terhadap pencapaian tujuan sasaran yang telah ditetapkan secara sederhana, efektivitas menggambarkan jangkauan akibat dan dampak dari keluaran program dalam mencapai tujuan program. (Astutik \& Makmur, 2012). Sedangkan Steers dalam Tangkilisan (2005:64) mengemukakan lima kriteria dalam pengukuran efektivitas organisasi yaitu:

1. Produktiviitas

2. Kemampuanad aptasi atau fleksibilitas

3. Kepuasan kerja

4. Keuntugan berlaba

5. Pencarian sumberdaya.

Pengertian Pajak Bumi dan Bangunan (PBB) menurut Undang-undang No. 28 tahun 2009 tentang Pajak Bumi dan Bangunan
(PBB) adalah iuran yang dikenakan terhadap pemilik, pemegang kekuasaan, penyewa dan yang memperoleh manfaat dari bumi dan atau bangunan. Undang-Undang No.12 tahun 1994 Pasal 4 ayat(1) Tentang Subjek Pajak Bumi dan Bangunan (PBB) adalah orang atau badan yang secara nyata mempunyai suatu hak atas bumi, dan atau memperoleh manfaat atas bumi, dan atau memiliki, menguasai, dan atau memperoleh manfaat atas bangunan.

\section{B. METODE PENELITIAN}

Penelitian deskriptif kuantitatif adalah nmetode penelitian yang digunakan untuk menemukan pengetahuan yang seluas seluasnya terhadap objek penelitian pada suatu masa tertentu. Populasi yang diambil dalam penelitian ini adalah seluruh kepala keluarga yang adadi KeLurahan Lawawoi Sebanyak 859 kepala keluarga. Jadi yangakan dijadikan sampel yaitu 86 orang/kepala keluarga. Pemilihan sampel dalam penelitiannya ini menggunakan probability Sampling. Teknik pengumpulan data yang digunakanadalah melakukan Observasi, Kuisioner, wawancara dan kepustakaan sedangkan teknikan alisis data yang digunakannya adalah teknik analisis data kuantitatif. Defenisi Operasional Variabel Menurut (Ahmad, 2015) defenisi operasional variabel adalah defenisi yang di dasarkan atas sifat-sifat variabel yang diamati. Defenisi operasional mencakup halhal penting dalampenelitianyang memerlukan penjelasan. Defenisi operasional variabel adalah pengertian variabel yang diungkap dalam defenisi konsep tersebut secara operasional, praktik, riel dan nyata dalam lingkup objek penelitian/obyek yang diteliti.

\section{HASIL PENELITIAN \& PEMBAHASAN}

1. Pengawasan. Rekapitulasi responden mengenai indikator pengawasan

Hasil rata-rata persentase dari 4 pertanyaan pada indikator pengawasan diatas, maka didapatkan hasil rata-rata persetase yaitu $75,5 \%$.Jadi dapat ditarik suatu kesimpulan bahwa pada indikator pengawasan ini berada dikategori baik/sesuai.

2. Efektivitas. Rekapitulasi tanggapan responden mengenai indikator Efektivitas

Hasil rata-rata persentase dari 4 pertanyaan pada indicator prestasi kerja di atas, maka didapatkan hasil rata-rata 
persentase yaitu48\%.Jadi dapat ditarik suatukesimpulan bahwa pada indicator efektivitas kerja iniberada dikategori kurang sesuai/kurang baik. Adapun total keseluruhan dari nilai dari Variabel $X$ (Strategi pengawasan) adalah 1021.Untuk mengetahui jumlah persentasenya, maka dapat dihitung dengan menggunakan rumus sebagai berikut:

\section{KESIMPULAN}

Berdasarkan hasil penelitian dan hasil pembahasan diatas maka dapat ditarik kesimpulan sebagai berikut :

1. Berdasarkan hasil peneliti dari indiaktor pengawasan, Maka didapatka hasil prensentase yaitu $75,5 \%$. jadi dapat ditarik suatu kesimpulan bahwa pada srategi pengawasa ini berada dikategorikan baik / sesuai.

2. Berdasarkan hasil peneliti dariindikator Efektivitas Pemungutan Pajak Bumi dan Bangunan,Makadidapatkahasilprensentase yaitu $48 \%$.jadidapatditariksuatukesimpulan pada Efektivitasini berada dikategorikan kurang baik / Tidak sesuai.

\section{E. REFERENSI}

Ahmad Jamaluddin.2015. Metode Penelitian AdministrasiPublikTeoridan Aplikasinya.Yogyakarta.Gama Media.

Arikunto,S.2016.ProsedurPenelitian,Suatu PendekatanPraktik.EdisiVI. Yogyakarta:Rhineka Cipta LaboloMuhadam.(2007).Memahamillmu Pemerintahan.Jakarta.RajaGrafindo Persada,

Pasolong,H.(2011)Teori Administrasi Publlik. Bandung:Alfabeta.

Pasolong,H.(2014)TeoriAdministrasiPublik. Bandung:Alfabeta.

Sugiyono.(2014).MetodePenelitianKuantitatif Kualitatif dan R\&D. Bandung : Alfabeta.

Sellang,K.(2016).Administrasi dan Pelayanan PublikAntaraTeoridanAplikasi. Yogyakarta : Ombak.

Steers, Richard,2016. Efektivitas Organisasi. : Jakarta:RienekaCipta.

The LiangGie,2014.PerilakuOrganisasidan Manajemen,Jakarta:Pustaka Jaya.
e-ISSN 2716-165X

Zainuddin.(2017).Teori-TeoriMutakhirdalam

Perspektif IlmuAdministrasi Publik.:

Makassar:PhinatamaMedia

Jurnal :

Anggraeni,D.(2011).Analisisstrategi pemungutan pajak bumi dan bangunan (pbb)dikotasurabayaterhadap

peningkatanrealisasitarget

penerimaannya dari tahun 2006-2011. EJournal.

Astutik,T.P.,\&Makmur,M.(2012).Efektivitas pemungutan pajak bumi dan bangunan untukmeningkatkanpendapatanasli daerah (studi padadinas pendapatan asli daerah kotamalang).E-Journal,2(1),4752.

Atmasepa,D.T.(2015).Pengawasanbadan pendapatandaerahterhadap pemungutan pajakbumidanbangunan(pbb)dikelurahan simpang baru kecamatan tampan kota pekanbaru tahun 2015. E-Journal,4(2), $1-15$.

Gunawan,yogiagus.(2015).Efektivitas

Pemungutan Pajak Bumi dan Bangunan di Kecamatan Sopai,KabupatenToraja Utara". E-Journal.

Hermansyah,A.A.(2015).Efektivitas

Pemungutan Pajak Bumi dan Bangunan

PerdesaanPerkotaan(PBB-P2)Di

DispendaKotaMakasar.IImuAdministrasi

Program StudiAdministrasi Negara.

idaAyuMetha Apsari Prathiwi, Nyoman Trisna Herawati,N.L.G.E.S.(2015).Analisis strategipenerimaanpajakbumidanbangun an pedesaan dan perkotaan(pbbp2) sertaefektivitaspenerimaannyadipemerint ah kota denpasar tahun 2013-2014. EJournal,3(1).

IndahK.Rumengan,DavidPaulEliaSaerang, T.R.(2016).Analisisefektivitasdan strategi penerimaan pajak bumi dan bangunan pedesaan perkotaan (pbb-p2) di dinas pengelola keuangan pendapatan dan aset kabupaten minahasa selatan. EJournal, 16(04), 763-772.

SURYANI,E.(2016).Efektivitaspemungutan pajakbumidanbangunan dinaspendapatan kabupaten pesawaran dalam peningkatan pendapatan asli daerah (pad). Journal Article. 
Dokumen :

Undang-undang Republik Indonesia Nomor 15 Tahun 2014 tentang pedoman standar pelayanan

Permendagri Nomor 58 Tahun 2010 tentang TahapanPersiapan Pengalihan PajakBumi dan Bangunan Pedesaan danPerkotaan sebagai PajakDaerah.

UndangUndang Nomor23 Tahun2014 Tentang Pemerintahan Daerah

Peraturan Pemerintah Republik Indonesia No. 17 Tahun 2018 pasal1 ayat(2) Tentang Kelurahan 